\title{
Interaction between plant species and substrate type in the removal of $\mathrm{CO} 2$ indoors
}

Article

Accepted Version

Gubb, C., Blanusa, T., Griffiths, A. and Pfrang, C. (2019) Interaction between plant species and substrate type in the removal of CO2 indoors. Air Quality, Atmosphere \& Health, 12 (10). pp. 1197-1206. ISSN 1873-9326 doi:

https://doi.org/10.1007/s11869-019-00736-2 Available at https://centaur.reading.ac.uk/85876/

It is advisable to refer to the publisher's version if you intend to cite from the work. See Guidance on citing.

To link to this article DOI: http://dx.doi.org/10.1007/s11869-019-00736-2

Publisher: Springer

All outputs in CentAUR are protected by Intellectual Property Rights law, including copyright law. Copyright and IPR is retained by the creators or other copyright holders. Terms and conditions for use of this material are defined in the End User Agreement.

www.reading.ac.uk/centaur 
Central Archive at the University of Reading

Reading's research outputs online 
1 Interaction between plant species and substrate type in the removal of $\mathrm{CO}_{2}$ indoors

3 Curtis Gubb ${ }^{1}$, Tijana Blanusa ${ }^{2,3}{ }^{*}$, Alistair Griffiths ${ }^{2}$ and Christian Pfrang ${ }^{1}$

$4{ }^{1}$ Department of Earth, Geography and Environmental Science, University of Birmingham, UK

$5{ }^{2}$ Science Department, Royal Horticultural Society, Garden Wisley, GU23 6QB, Woking, UK

$6{ }^{3}$ School of Agriculture, Policy and Development, University of Reading, RG6 6AS, Reading, UK

7

$8 *$ *corresponding author

9 tijanablanusa@rhs.org.uk

10 Telephone: +44-118-378-6628

11

12

13

14

15 Acknowledgments

16 This work was supported by the Royal Horticultural Society (RHS) and the Engineering and Physical Sciences

17 Research Council (EPSRC). The authors would also like to thank Dr Dalila Touhami, Rob Stirling, Kaan Alkan, David

18 Tubbs, Nicholas Davidson, Val Jasper, Matthew Richardson, Liam Doherty, Will Johnson and Michael Dawes for their

19 practical guidance and support. 


\section{Highlights}

2

3 Substrate type has a significant impact on the ability of indoor plants to remove $\mathrm{CO}_{2}$

4 Plants were unable to reduce the $1000 \mathrm{ppm} \mathrm{CO}_{2}$ at typical indoor light levels

5 Plants were able to remove $1000 \mathrm{ppm} \mathrm{CO}_{2}$ at a light level of 22200 lux

6 Respiration was deemed negligible in comparison to human contributions 


\section{Abstract}

Elevated indoor concentrations of carbon dioxide $\left[\mathrm{CO}_{2}\right]$ cause health issues, increase workplace absenteeism

4 and reduce cognitive performance. Plants can be part of the solution, reducing indoor $\left[\mathrm{CO}_{2}\right]$ and acting as a low-cost 5 supplement to building ventilation systems.

6 Our earlier work on a selection of structurally and functionally different indoor plants identified a range of 7 leaf-level $\mathrm{CO}_{2}$ removal rates, when plants were grown in one type of substrate. The work presented here brings the 8 research much closer to real indoor environments by investigating $\mathrm{CO}_{2}$ removal at a whole-plant level and in 9 different substrates. Specifically, we measured how the change of growing substrate affects plants' capacity to 10 reduce $\mathrm{CO}_{2}$ concentrations. Spathiphyllum wallisii 'Verdi', Dracaena fragrans 'Golden Coast' and Hedera helix, 11 representing a range of leaf types and sizes and potted in two different substrates, were tested. Potted plants were 12 studied in a $0.15 \mathrm{~m}^{3}$ chamber under 'very high' (22000 lux), 'low' ( 500 lux) and 'no' light (0 lux) in 'wet' (> 30 \%) and 13 'dry' $(<20 \%)$ substrate.

14 At 'no' and 'low' indoor light, houseplants increased the $\mathrm{CO}_{2}$ concentration in both substrates; respiration 15 rates, however, were deemed negligible in terms of the contribution to a room-level concentration, as they added $160.6 \%$ of a human's contribution. In 'very high' light $D$. fragrans, in substrate 2 , showed potential to reduce $\left[\mathrm{CO}_{2}\right]$ to a 17 near-ambient (600 ppm) concentration in a shorter timeframe (12 hrs, e.g. overnight) and S. wallisii over a longer 18 period (36 hrs, e.g. weekend). 


\section{Keywords}

2

3 Indoor air quality, houseplants, indoor light, Dracaena, Spathiphyllum, Hedera

4

5 


\section{Abbreviations:}

2

3 ASHRAE: The American society of heating, refrigeration and air-conditioning engineers

4 SMC: $\quad$ Substrate moisture content $\left(\mathrm{m}^{3} \mathrm{~m}^{-3}\right)$

5 VOCs: Volatile organic compounds

6 ANOVA: Analysis of variance

7 SEM: $\quad$ Standard error of the mean 
Elevated indoor concentrations of $\mathrm{CO}_{2}(>600 \mathrm{ppm})$ are harmful to human health, increase absenteeism and reduce cognitive performance (Seppanen et al., 1999; Erdmann and Apte, 2004; Shendell et al., 2004; Shaughnessy et al., 2006; Gaihre et al., 2014; Zhang et al., 2017). Traditional building ventilation systems are designed to keep $\mathrm{CO}_{2}$ concentrations near-ambient with outdoor air infiltration, albeit increasing building energy consumption (PerezLombard et al., 2008). Indoor plants can act as a simple low-cost form of ventilation, reducing indoor ventilation requirements (by $\sim 6 \%$ ) with $\mathrm{CO}_{2}$ removal and consequently providing a reduction in building energy consumption, but only under certain environmental conditions i.e. a very high light level ( 22000 lux) - as confirmed by several previous studies (Torpy et al., 2014; Torpy et al., 2017; Gubb et al., 2018).

Numerous health guidelines exist for maximum safe $\mathrm{CO}_{2}$ concentrations, the lowest of these being $1000 \mathrm{ppm}$ produced by the American society of heating, refrigeration and air-conditioning engineers (ASHRAE) - a concentration often exceeded indoors (Shendell et al., 2004; Gaihre et al., 2014; Torpy et al., 2014; Torpy et al., 2017). Concentrations indoors are typically less than $2000-2500 \mathrm{pm}$, but can rise as high as $5000 \mathrm{ppm}$, with the main source of $\mathrm{CO}_{2}$ indoors being humans themselves (Zhang et al., 2017).

Elevated $\mathrm{CO}_{2}$ concentrations (> $600 \mathrm{ppm}$ ) can cause an array of health issues including eye irritation, mucus membrane symptoms (i.e. sore/dry throat, dry eyes and sneezing) and respiratory problems (i.e. tight chest, wheezing/coughing and shortness of breath) (Seppanen et al., 1999; Erdmann and Apte, 2004; Tsai et al., 2012).

Additionally, elevated concentrations have been associated with declines in cognitive function (at $950 \mathrm{ppm}$ ); absenteeism, with increases of 100 ppm associated with a reduced annual attendance of half a day per annum and reductions in cognitive performance, with concentrations of $600-1000 \mathrm{ppm}$ found to significantly reduce decision making ability (Shaughnessy et al., 2006; Satish et al., 2012; Gaihre et al., 2014; Vehvilainen et al., 2016; Allen et al., 2016).

Several studies have shown that light levels significantly influence a plants ability to remove $\mathrm{CO}_{2}$ via their impact on stomata as a main pathway for $\mathrm{CO}_{2}$ uptake (Pennisi and van lersel, 2012; Torpy et al., 2014; Torpy et al., 2017; Gubb et al., 2018). Indoors, the light level is typically between 0-500 lux, but can be as high as 3000 lux in certain workplace environments (Boyce and Raynham, 2009; Lai et al., 2009; Hawkins, 2011; Huang et al., 2012). Often, supplementary lighting is required to support specific plant installations such as a green wall, where higher light levels are utilised above the installation and not throughout the entire room - this supplementary light can be engineered at least as high as 22200 lux (Gubb et al., 2018). Plants' under- or over-watering also affects a plant's ability to remove $\mathrm{CO}_{2}$ (Sailsbury and Ross, 1991) but our previous work showed that indoor light level was the primary driver of $\mathrm{CO}_{2}$ uptake and the soil drying had smaller impact (Gubb et al., 2018).

Plants remove airborne pollutants via four different pathways: the aboveground plant part (by photosynthesis, deposition and/or diffusion through the waxy layer), the roots (by deposition and/or direct uptake), and two of which directly involve the substrate - namely, sorption by the substrate itself, along with breakdown by the microbial activity within the substrate (Cruz et al., 2014). It can therefore be expected that both the type and 
condition (wet/dry) of the substrate will affect plants $\mathrm{CO}_{2}$ removal ability. Experiments investigating the ability of plants to remove volatile organic compounds (VOCs) have found that the removal of VOCs is predominately associated with the microflora in the substrate, plants themselves are only utilised indirectly to maintain and support substrate microorganisms (Wood et al., 2002; Orwell et al., 2004; Kim et al., 2008; Cruz et al., 2014; Irga et al., 2018; Kim et al., 2018); these microorganisms - especially those associated with the root system - have been shown to metabolise an array of different pollutants (Weyens et al., 2015).

Various substrates are available in the UK for growing indoor plants, including various types of peat and peat-free (Barrett et al., 2016). Peat - an organic material - is a limited resource, hence attempts by the UK commonly used across the UK because of their uniformity, providing easier water management (Schmilewski, 2008; Alexander et al., 2013). Peat has been shown to have higher water-holding capacity compared to some alternatives such as coir, sand and wood fibres (Schmilewski, 2008). As several studies have linked soil moisture to microbial respiration, an investigation into substrates moisture content is of significance to $\mathrm{CO}_{2}$ removal (Cook et al., 1985; Manzoni, 2012). Furthermore, with different substrate types able to support different microorganisms (Zhang et al., 2013) it was hypothesised that differences in removal would be measured between our chosen substrates. Therefore, two different substrates (peat free and peat) -referred to as Substrate 1 and Substrate 2, respectively, within this paper - were chosen for this experiment to determine to what extent they affected plants' ability to remove $\mathrm{CO}_{2}$ within test chambers. We hypothesised that growing the same taxa in differing substrates might provide differing $\mathrm{CO}_{2}$ removal abilities.

If houseplants are to reduce elevated $\mathrm{CO}_{2}$ concentrations, they must be functioning optimally i.e. experience appropriate light levels, feeding and watering (i.e. substrate moisture content - SMC). A few studies have investigated these issues in part, testing various plants potted in different peat-free substrates (Irga et al., 2013; Torpy et al., 2014; Torpy et al., 2017; Gubb et al., 2018)

Torpy et al., 2014 determined the light response curves of eight common plants potted a peat-free substrate consisting of composted hardwood, sawdust, composted bark fines, and coarse river sand (2:2:1). These authors suggested that in typical 'low' indoor light some $\mathrm{CO}_{2}$ removal could be expected but, moderately increasing light levels would mean the studied plants could be effectively utilised in a built environment setting. (Torpy et al., 2017) also investigated the ability of two taxa (Chlorophytum comosum and Epipremnum aureum) potted in a peat-free substrate comprising of coconut fibre - as part of an active green-wall - to remove $1000 \mathrm{ppmv}$ of $\mathrm{CO}_{2}$ at light levels of 50 and $250 \mu \mathrm{mol} \mathrm{m} \mathrm{m}^{-2}$. The study found removal was much more effective at $250 \mu \mathrm{mol} \mathrm{m}^{-2} \mathrm{~s}^{-1}$ and found that removal from a $5 \mathrm{~m}^{2}$ wall of $C$. comosum could balance the respiratory emissions of a full-time occupant.

Our research aims to test which houseplants together with the substrate they are grown in (from now on referred to as houseplants or taxa) can best reduce $\mathrm{CO}_{2}$ concentration of $1000 \mathrm{ppm}$ under differing environmental and growing conditions. Specifically we tested the selected taxa:

- Under three light levels: 'very high' ( 22000 lux), typical 'low' light ( 500 lux) and 'no' indoor light (0 lux);

- In 'wet' (SMC > 30\%, $\left.0.3 \mathrm{~m}^{3} \mathrm{~m}^{-3}\right)$ and 'dry' (SMC $\left.<20 \%, 0.2 \mathrm{~m}^{3} \mathrm{~m}^{-3}\right)$ substrate moisture conditions; 
- With two different substrate types.

Zero lux $\left(0 \mu \mathrm{mol} \mathrm{m} \mathrm{m}^{-2}\right)$ was chosen to investigate $\mathrm{CO}_{2}$ assimilation/respiration in the dark; $\sim 500$ lux ( 7 $\mu \mathrm{mol} \mathrm{m} \mathrm{m}^{-2}$ ) was chosen to represent typical office conditions; 22000 lux ( $\left.\sim 300 \mu \mathrm{mol} \mathrm{m} \mathrm{m}^{-2} \mathrm{~s}^{-1}\right)$ was chosen to represent the highest technically feasible light level which could be engineered indoors (with supplementary artificial lighting) (Torpy et al., 2017).

This experiment was undertaken on a whole plant/substrate scale as opposed to leaf-level experiments investigated in prior work (Gubb et al., 2018). It was hypothesised that experiments on this larger scale would provide more accurate estimations for how plants can influence 'room-scale' concentrations of $\mathrm{CO}_{2}$. Additionally, this study looks to highlight if substrate type can make a difference to the $\mathrm{CO}_{2}$ removal ability of taxa and justify the need for further research with a more extensive range of appropriate substrates in subsequent studies.

\section{Material and Methods}

\subsection{Plant material}

Three common houseplant taxa (Dracaena fragrans 'Golden Coast', Hedera helix and Spathiphyllum wallisii 'Verdi') which were shown in our previous study to have a range of $\mathrm{CO}_{2}$ removal capacities were selected for this study. They represented a range of leaf types (succulent and herbaceous) and plant sizes (Table 1). Plants were maintained in either 'Substrate 1- peat-free substrate i.e. Sylvamix growing medium (Melcourt, Tetbury, Gloucestershire, UK; 6:2:2 sylvafibre: growbark pine: coir; air-filled porosity, 21\%; moisture content by weight, 60\%) or in 'Substrate 2' - peat substrate i.e. Clover professional pot bedding substrate (100\% Irish Moss Peat; Clover, Dungannon, Co. Tyrone, UK). Plants were maintained in $3 \mathrm{~L}$ containers, with a slow release fertiliser feed (6-9 months, Osmocote, Marysville, OH, USA). Plants were purchased in Summer 2016 (apart from Dracaena fragrans 'Golden Coast' in Substrate 2, which was purchased in Spring 2018). Prior to experimentation (for > 90 days) plants were kept at room temperatures $\left(17-22^{\circ} \mathrm{C}\right)$ and 'low' light levels ( 500 lux) in an indoor office environment within the Crops Laboratory in the Glasshouse Complex of the School of Agriculture, Policy and Development, at the University of Reading (UK). Hedera helix could not be successfully grown in the Substrate 2 and was omitted from the study in this substrate after several failed attempts.

Table 1: Characteristics of the houseplant taxa chosen for experiments in both substrates. Leaf area $(n=3)$ and plant height $(n=5)$ are means \pm SEM. Species' botanical Latin name is given in italic and cultivar, where applicable, follows.

\begin{tabular}{lllll}
\hline Taxa - Substrate 1 & Family & Metabolism & Leaf area $\left(\mathrm{cm}^{2}\right)$ & Plant height $(\mathrm{cm})$ \\
\hline Dracaena fragrans 'Golden Coast' & Asparagaceae & C3 & $4057 \pm 337$ & $83 \pm 1$ \\
Hedera helix & Araliaceae & C3 & $1542 \pm 122$ & $8 \pm 1$ \\
Spathiphyllum wallisii 'Verdi' & Araceae & C3 & $6033 \pm 128$ & $38 \pm 1$ \\
\hline
\end{tabular}

\begin{tabular}{lllll}
\hline Taxa - Substrate 2 & Family & Metabolism & Leaf area $\left(\mathrm{cm}^{2}\right)$ & Plant height $(\mathrm{cm})$ \\
\hline Dracaena fragrans 'Golden Coast' & Asparagaceae & C3 & $1417 \pm 112$ & $48 \pm 1$
\end{tabular}




\section{$2.2 \mathrm{CO}_{2}$ Chamber experiments}

Experiments were carried out in an experimental laboratory with a non-bypass fume hood at the University of Reading (UK). The experimental setup (Figure 1) consisted of a 150 L (45 x $\left.45 \times 75 \mathrm{~cm}, 0.15 \mathrm{~m}^{3}\right)$ Perspex chamber 5 (The plastic people, Leeds, West Yorkshire, UK) connected to a $\mathrm{CO}_{2}$ cylinder $\left(\mathrm{CO}_{2}>99 \%\right.$ purity, Air Liquide, Coleshill, 6 West Midlands, U.K) with a combination of Teflon tubing ( $1 \frac{1}{4}$ inch diameter) and Swagelok's (Swagelok, Bristol, South

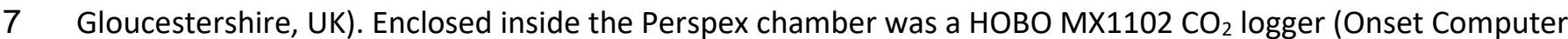
8 Corporation, Bourne, MA, U.S.A), a 12 V DC brushless fan (RS Components, Corby, Northants, UK), $500 \mathrm{~g}$ of silica gel 9 (Sigma - Aldrich Company Ltd, Gillingham, Dorset, U.K) and a calibrated $\left(20-90 \% \mathrm{RH}, 0-40^{\circ} \mathrm{C}\right.$ ) Tinytag RH/temperature logger (Gemini data loggers, Chichester, West Sussex, UK). The external RH/temperature surrounding the chamber was also monitored with another, identical Tinytag logger. Inside the chamber 'no' ( 0 lux, 0 $\left.\mu \mathrm{mol} \mathrm{m} \mathrm{m}^{-1}\right)$ light was achieved by undertaking at experiments at night; 'low' ( 500 lux, $\sim 7 \mu \mathrm{mol} \mathrm{m} \mathrm{s}^{-2}$ ) light levels were achieved in the usual lighting conditions of the room (four fluorescent ceiling lights, Osram, Munich, Germany lighting a floor area of $11 \mathrm{~m}^{2}$ ); 'very high' levels were achieved with two LED lights (V-TAC Europe Ltd, Sofia, Bulgaria) which were positioned on stands externally, one at an $30 \mathrm{~cm}$ height above the chamber and another $\sim 30 \mathrm{~cm}$ from the side of the chamber. Colour temperature of those lights was $6000 \mathrm{k}$ and both lights combined produced a 'very high' ( 22000 lux, $300 \mu \mathrm{mol} \mathrm{m} \mathrm{s}^{-1}$ ) light level inside the chamber - all three levels were measured with a calibrated light sensor (SKP 200, Skye instruments, Llandrindod Wells, Wales, UK). This 'very high' light level approximately corresponds to the light saturation for the studied species on a light response curve (Gubb et al., 2018) and was chosen to represent the highest feasible light level which could be engineered (with supplementary artificial lighting) in an indoor environment.

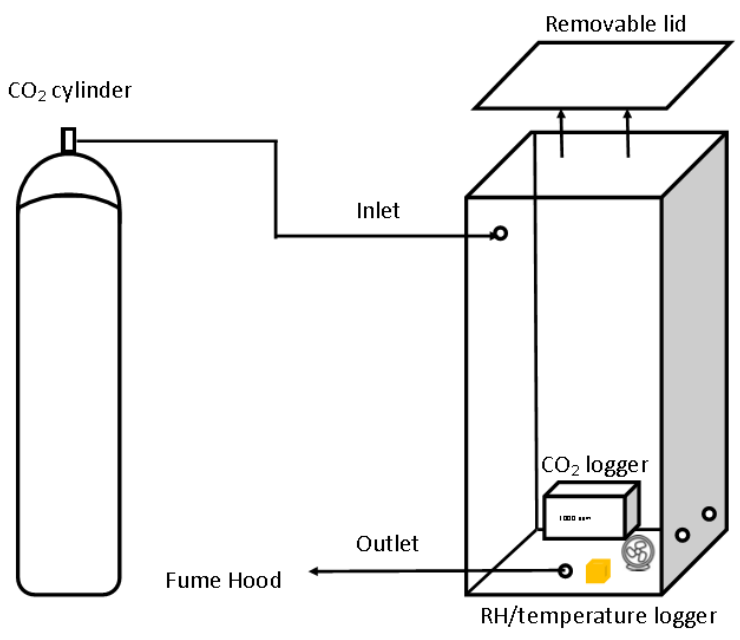

A

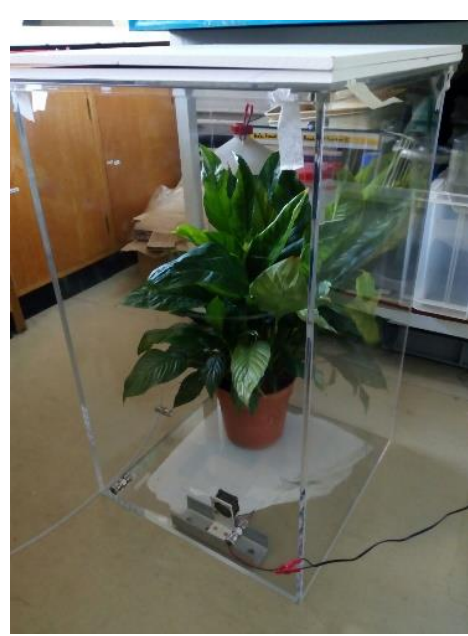

B

23 Figure 1: Schematic diagram (A) and image (B) of the $\mathrm{CO}_{2}$ chamber experimental setup 
Measurements of the ability of studied taxa to reduce $\mathrm{CO}_{2}$ concentrations of $1000 \mathrm{ppm}$ (ASHRAE recommended maximum $8 \mathrm{hr}$ exposure guideline taken from Torpy et al., 2014; Torpy et al., 2017) were undertaken on either three ('no' and 'low' light) or five ('very high' light) plants per taxon. Taxa were prepared for experiments with substrate moisture at the container capacity $(\mathrm{SMC}>30 \%)$ and plants were thus considered optimally watered on the commencement of each experiment (Vaz Monteiro et al., 2016). Measurements were also made on each houseplants 'dry' substrate $(S M C<20 \%)$ after a period of drying - the length of which was dependent on the type of plant and its inherent evapo-transpiration rate (Gubb et al., 2018). To ascertain when each taxon was 'dry' SMC was probe connected to a HH2 Moisture Meter (Delta-T Devices, Cambridge, Cambridgeshire, UK; 0-100\% range and an accuracy of $\pm 2.5 \%$ ). Experiments were made on one whole 'plant - substrate system' (i.e. potted plant, with uncovered substrate) enclosed inside the Perspex chamber at a $\mathrm{CO}_{2}$ concentration of $1000 \mathrm{ppm}( \pm 10 \%)$. Experiments were for a duration of $1 \mathrm{hr}$ with the $\mathrm{CO}_{2}$ concentration logged every second. Appropriate 'control' measurements were run at all three light levels on both the empty chamber and pot with substrate, but no plant (in both 'wet' and 'dry' SMC). The number of runs with only substrate and pot were either three for 'no' and 'low' light or five for 'very high' light.

Experimental parameters for each lighting treatment were as follows: 'no' light, ambient $\left(\mathrm{CO}_{2}<500 \mathrm{ppm}\right.$; Temperature $17-26^{\circ} \mathrm{C} ; \mathrm{RH} 23-64 \%$ ) and inside chamber (Temperature $17-26^{\circ} \mathrm{C} ; \mathrm{RH} 31-90 \%$, average $61 \%$ ); 'low' light, ambient $\left(\mathrm{CO}_{2}<500\right.$ ppm; Temperature $13-23^{\circ} \mathrm{C}$; RH $\left.24-61 \%\right)$ and inside chamber (Temperature $13-$ $24{ }^{\circ} \mathrm{C}$; RH $36-90 \%$, average 68\%); and high light, ambient ( $\mathrm{CO}_{2}<500$ ppm; Temperature $15-22{ }^{\circ} \mathrm{C}$; $\left.\mathrm{RH} 21-60 \%\right)$ and inside chamber (Temperature $15-24^{\circ} \mathrm{C}$; RH $32-90 \%$, average 64\%). The chamber was also analysed for leakage prior, during and after experimentation; leakage was found to be $<5 \%$ of the starting concentration over the test period. All results were corrected for leakage. This was achieved - for 'no' and 'low' light - by adding the average $\mathrm{CO}_{2}$ concentration lost through leakage (ppm) to the amount of $\mathrm{CO}_{2}$ respired by each taxon (ppm) - correcting for the fact that each taxon would have measured a greater concentration of $\mathrm{CO}_{2}$ if the chamber was airtight. The opposite was done for 'very high' light, correcting for the fact that each taxon would have removed more $\mathrm{CO}_{2}$ if the chamber was airtight.

Based on the findings of our previous leaf-level work with the same taxa (Gubb et al., 2018) we hypothesised that at 'no' and 'low' indoor light levels taxa would increase $\mathrm{CO}_{2}$ concentrations within the enclosure. The $\mathrm{CO}_{2}$

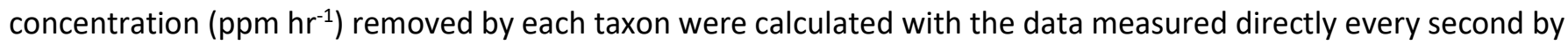
the appropriate logger and divided by the leaf area in $\mathrm{m}^{2}$ presented in Table 1 to give a unit of $\mathrm{ppm} \mathrm{m}^{-2} \mathrm{~h}^{-1}$.

\subsection{Statistical analysis}

Experimental data ( $\mathrm{CO}_{2}$ concentrations) were analysed using GENSTAT (17th Edition, VSN International, Hemel Hempstead, Hertfordshire, UK). An analysis of variance (ANOVA) was performed to compare means for each measured parameter between different taxa and/or over time. Variance levels were checked for homogeneity and 
1 values were presented as means with either associated least significant differences (Isd) at a 5\% significance level,

2 standard error of the mean (SEM) or as Tukey's 95\% confidence intervals for multiple comparisons. Where a Isd or

3 Tukey's confidence interval has been used for data comparison, the associated p-value is presented. Where this is

4 not displayed SEM has been used.

5

63 Results

$7 \quad 3.1 \mathrm{CO}_{2}$ chamber experiments - 'no' light

8 At 'no' indoor light no taxa reduced $\mathrm{CO}_{2}$ from the initial $1000 \mathrm{ppm}$ concentration, and the $\mathrm{CO}_{2}$ concentration

9 inside the chamber increased with all treatments; no statistically significant differences in concentration were

10 measured within taxon between 'dry' or 'wet' conditions (Table 2). Additionally, statistical differences were

11 measured between the Substrates 1 and 2 for Dracaena fragrans 'Golden Coast' in both 'dry' (331 and 138 ppm m²

$12 \mathrm{hr}^{-1}$, respectively; Table 2) and 'wet' conditions (332 and $151 \mathrm{ppm} \mathrm{m}^{-2} \mathrm{hr}^{-1}$, respectively; Table 2). 
1 Table 2: Mean $\mathrm{CO}_{2}$ increase in the chamber per $\mathrm{m}^{2}$ of leaf area for each taxon potted in the two substrates at 'no' (0 2 lux, $\left.0 \mu \mathrm{mol} \mathrm{m} \mathrm{s}^{-1}\right)$ indoor light in 'wet' (SMC > 30\%, $0.3 \mathrm{~m}^{3} \mathrm{~m}^{-3}$ ) and 'dry' (SMC $\left.<20 \%, 0.20 \mathrm{~m}^{3} \mathrm{~m}^{-3}\right)$ conditions. Data 3 are a mean of three plants per taxon \pm SEM.

Taxa - Substrate 1

Dracaena fragrans 'Golden Coast' Hedera helix

Spathiphyllum wallisii 'Verdi'

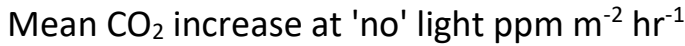

\begin{tabular}{cc}
\hline 'Wet' $(>30 \%$ SMC) & 'Dry' $(<20 \%$ SMC) \\
\hline $332 \pm 24$ & $331 \pm 18$ \\
$745 \pm 189$ & $408 \pm 148$ \\
$177 \pm 30$ & $155 \pm 15$
\end{tabular}

Taxa - Substrate 2

Dracaena fragrans 'Golden Coast'

Mean $\mathrm{CO}_{2}$ increase at 'no' light ppm $\mathrm{m}^{-2} \mathrm{hr}^{-1}$

Spathiphyllum wallisii 'Verdi'

\begin{tabular}{cc}
\hline 'Wet' (> 30 \% SMC) & 'Dry' (<20\% SMC) \\
\hline $151 \pm 78$ & $138 \pm 67$ \\
$228 \pm 42$ & $185 \pm 18$
\end{tabular}

\section{$63.2 \mathrm{CO}_{2}$ chamber experiments - 'low' light}

At 'low' indoor light Spathiphyllum wallisii 'Verdi' potted in the Substrate 2 reduced the concentration of $\mathrm{CO}_{2}$ 8 from the initial 1000 ppm concentration ('dry' and 'wet', 43 and 1 ppm m${ }^{-2} \mathrm{hr}^{-1}$, respectively; Table 3). All other 9 plant/substrate combinations increased the $\mathrm{CO}_{2}$ concentration. Statistically significant differences were measured 10 within taxon between 'dry' and 'wet' conditions for Hedera helix in the Substrate 1 (379 and 518 ppm m$^{-2} \mathrm{hr}^{-1}$, 11 respectively; Table 3). Additionally, statistical differences in removal were measured between the two substrates for 12 Spathiphyllum wallisii 'Verdi' in 'wet' conditions (227 and $-1 \mathrm{ppm} \mathrm{m} \mathrm{m}^{-2} \mathrm{hr}^{-1}$, respectively; $\mathrm{p}=0.03$; Table 3) but not 'dry' (192 and -43 ppm m ${ }^{-2} \mathrm{hr}^{-1}$, respectively, $\mathrm{p}=0.126$; Table 3) and for Dracaena fragrans 'Golden Coast' in 'dry' conditions (147 and $7 \mathrm{ppm} \mathrm{m}^{-2} \mathrm{hr}^{-1}$, respectively, Table 3). 
1 Table 3: Mean $\mathrm{CO}_{2}$ increase in the chamber per $\mathrm{m}^{2}$ of leaf area for each taxon potted in the two substrates at 'low' ( 2500 lux, $7 \mu \mathrm{mol} \mathrm{m} \mathrm{m}^{-2}$ ) indoor light in 'wet' (SMC $>30 \%, 0.3 \mathrm{~m}^{3} \mathrm{~m}^{-3}$ ) and 'dry' (SMC $<20 \%, 0.20 \mathrm{~m}^{3} \mathrm{~m}^{-3}$ ) conditions. 3 Data are a mean of three plants per taxon $\pm \mathrm{SEM},(-)$ values signify $\mathrm{CO}_{2}$ assimilation (i.e. $\mathrm{CO}_{2}$ uptake by the plant thus 4 its removal from the chamber).

\begin{tabular}{lcc}
\hline \multirow{2}{*}{ Taxa - Substrate 1 } & \multicolumn{2}{c}{ Mean $\mathrm{CO}_{2}$ increase at 'low' light ppm m $^{-2} \mathrm{hr}^{-1}$} \\
\cline { 2 - 3 } Dracaena fragrans 'Golden Coast' & 'Wet' $(>30 \% \mathrm{SMC})$ & 'Dry' $(<20 \% \mathrm{SMC})$ \\
\cline { 2 - 3 } Hedera helix & $142 \pm 8$ & $147 \pm 13$ \\
Spathiphyllum wallisii 'Verdi' & $518 \pm 42$ & $379 \pm 54$ \\
\hline
\end{tabular}

\begin{tabular}{lcc}
\hline \multirow{2}{*}{ Taxa - Substrate 2 } & \multicolumn{2}{c}{ Mean $\mathrm{CO}_{2}$ increase at 'low' light ppm $\mathrm{m}^{-2} \mathrm{hr}^{-1}$} \\
\cline { 2 - 3 } & 'Wet' $(>30 \% \mathrm{SMC})$ & 'Dry' $(<20 \% \mathrm{SMC})$ \\
\cline { 2 - 3 } Dracaena fragrans 'Golden Coast' & $66 \pm 68$ & $7 \pm 52$ \\
Spathiphyllum wallisii 'Verdi' & $-1 \pm 38$ & $-43 \pm 64$ \\
\hline
\end{tabular}

$7 \quad 3.3 \mathrm{CO}_{2}$ chamber experiments - 'very high' light

At 'very high' indoor light all treatments reduced the concentration of $\mathrm{CO}_{2}$ from the initial $1000 \mathrm{ppm}$.

9 Significant differences were measured in $\mathrm{CO}_{2}$ reduction between all taxa, under both 'dry' and 'wet' conditions and between the two substrates (Figure 2). The range of removal rates was the smallest at 15 mins and the largest at 60 mins in both 'wet' and 'dry' conditions. After 15 minutes, no statistically significant differences in $\mathrm{CO}_{2}$ reduction were measured within the same taxon in either substrate between 'dry' and 'wet' conditions. After 60 minutes, statistically significant differences were measured in both Spathiphyllum and Dracaena potted in the Substrate 2 between 'dry' and 'wet' conditions, but not in the Substrate 1 (Figure 2).

In 'wet' conditions after 15 minutes, no statistically significant differences were measured between any studied taxa in either substrate (Figure 2, $p=0.550$ ). After 60 minutes, Dracaena fragrans 'Golden Coast' in the Substrate 2 reduced statistically the largest amount of $\mathrm{CO}_{2}$ from the initial $1000 \mathrm{ppm}$ concentration (1420 ppm m-2 $\left.\mathrm{hr}^{-1} ; \mathrm{p}<0.001\right)$. No statistically significant differences in $\mathrm{CO}_{2}$ removal were measured between Spathiphyllum wallisii 'Verdi' (623 ppm m$\left.{ }^{-2} \mathrm{hr}^{-1}\right)$ in Substrate 2 or any of the taxa potted in Substrate 1 - Hedera helix, Spathiphyllum wallisii 'Verdi' and Dracaena fragrans 'Golden Coast' (541, 436 and 463 ppm m${ }^{-2} \mathrm{hr}^{-1}$, respectively; $\mathrm{p}<0.001$; Figure 2).

In 'dry' conditions after 15 minutes, no statistically significant differences were measured between any studied taxa in either substrate (Figure 2, $p=0.221$ ). After 60 minutes, Dracaena fragrans 'Golden Coast' in Substrate 2 reduced statistically the largest amount of $\mathrm{CO}_{2}$ from the initial $1000 \mathrm{ppm}$ concentration $\left(1703 \mathrm{ppm} \mathrm{m}^{-2} \mathrm{hr}^{-1} \mathrm{p}<\right.$ 0.001). A statistically significant difference was measured between Spathiphyllum wallisii 'Verdi' $\left(820 \mathrm{ppm} \mathrm{m}^{-2} \mathrm{hr}^{-1}\right)$ in Substrate 2 and Hedera helix in the Substrate $1\left(401 \mathrm{ppm} \mathrm{m}^{-2} \mathrm{hr}^{-1} ; \mathrm{p}<0.001\right)$. No statistically significant differences were measured between other studied taxa i.e. Spathiphyllum wallisii 'Verdi' and Dracaena fragrans 'Golden Coast' (524 and $470 \mathrm{ppm} \mathrm{m}^{-2} \mathrm{hr}^{-1}$, respectively; $\mathrm{p}<0.001$; Figure 2 ). 

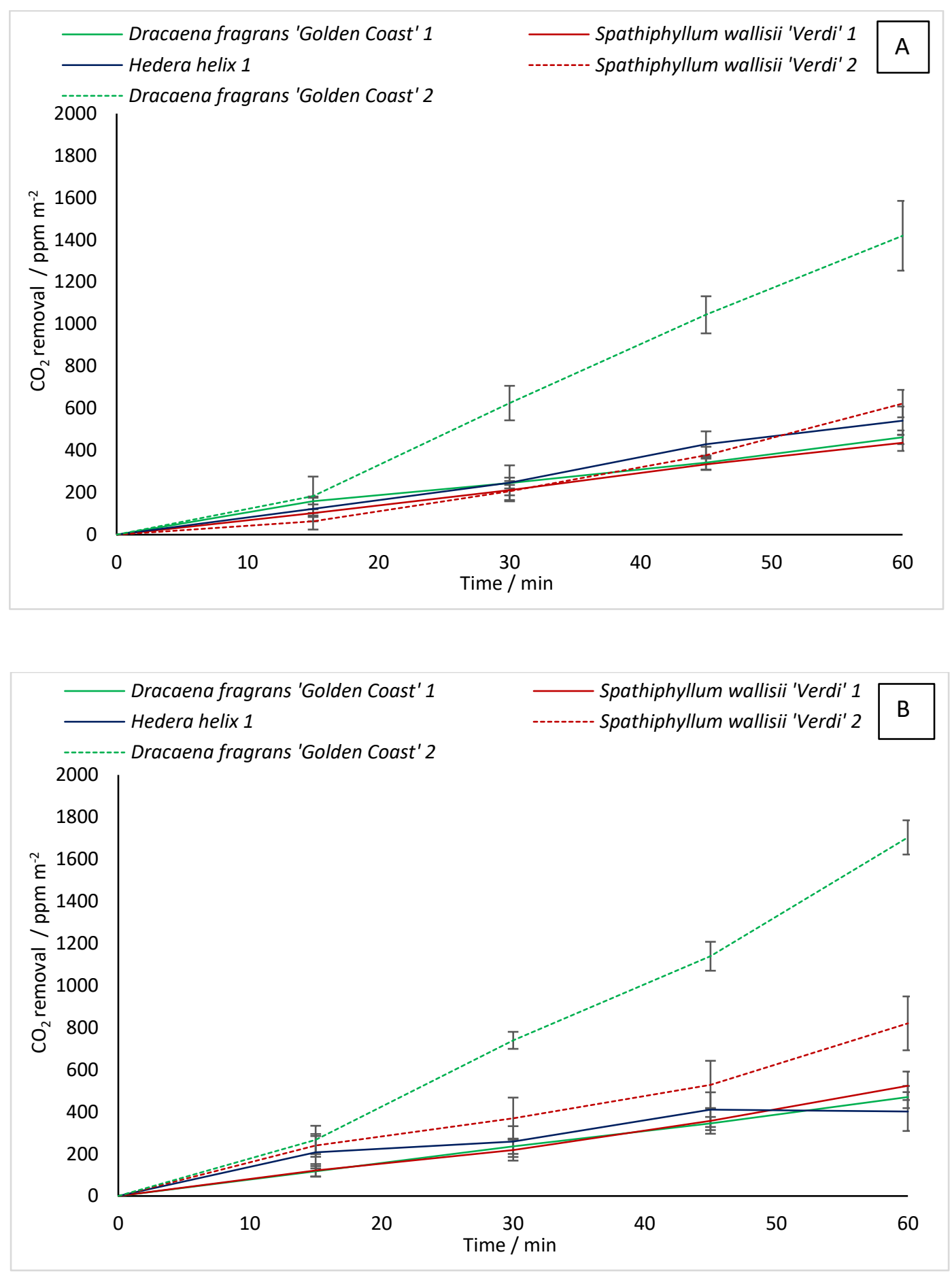

2 Figure 2: Mean $\mathrm{CO}_{2}$ removal by each taxon in substrates 1 and 2 at 'very high' indoor light ( 22000 lux, $300 \mu \mathrm{mol}$ $3 \mathrm{~m}^{-2} \mathrm{~s}^{-1}$ ) per $\mathrm{m}^{2}$ of leaf area in 'wet' (SMC > 30\%, $\left.0.3 \mathrm{~m}^{3} \mathrm{~m}^{-3}\right)(\mathrm{A})$, and 'dry' (SMC $<20 \%, 0.20 \mathrm{~m}^{3} \mathrm{~m}^{-3}$ ) (B) conditions 4 over a 60 min period. Data are a mean of five plants per taxa - error bars represent SEM. 
This work investigates how potting common houseplants in two differing substrates influenced their ability to reduce a harmful $\mathrm{CO}_{2}$ concentration of $1000 \mathrm{ppm}$ at a whole plant/substrate scale.

In this study we demonstrated that at 'low' light in 'dry' substrate conditions assimilation occurred with Spathiphyllum wallisii 'Verdi' potted in Substrate $2\left(-43 \mathrm{ppm} \mathrm{m}^{-2} \mathrm{hr}^{-1}\right)$ but not in Substrate $1\left(192 \mathrm{ppm} \mathrm{m}^{-2} \mathrm{hr}^{-1}\right)$, contrary to the initial hypothesis where an increase in $\mathrm{CO}_{2}$ concentration was expected from all studied taxa (Gubb et al., 2018). Similarly, the study found that Dracaena fragrans 'Golden Coast' was the most effective taxon at reducing high concentrations of $\mathrm{CO}_{2}$ at 'very high' indoor light levels when potted in the Substrate 2 (1703 ppm m${ }^{-2}$

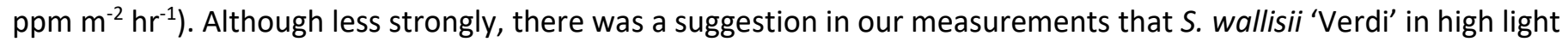
removed more $\mathrm{CO}_{2}$ by the end of a 60 minute period, when potted in Substrate 2 compared to Substrate 1.

These measurements suggest that differing substrate types may be able to influence $\mathrm{CO}_{2}$ assimilation. $\mathrm{A}$ taxon may grow more effectively and be more physiologically active in a particular substrate, facilitating a stronger $\mathrm{CO}_{2}$ removal ability. Peat has long been cited as a substrate which supports good plant growth, having good air-filled porosity, high water-holding capacity and a relatively pest- and pathogen-free environment (Schmilewski, 2008). Moreover, peat contains a carbon concentration in the range of $30-70 \mathrm{~kg} / \mathrm{m}^{3}(18-60 \%)$ whereas, for other mineral soils this concentration is typically $<20 \%$ (Agus et al., 2011), this additional carbon might be a possible reason for greater $\mathrm{CO}_{2}$ sequestration in our Substrate 2. Alternatively, the substrate and plant combined may support differing microorganisms, which in turn could provide a superior removal ability (Zhang et al., 2013). This however, would need to be explored further by evaluation of the differing microorganisms in both substrates and additional inoculation experiments with the microorganism species in question (De Kempeneer et al., 2004). Moreover, studies have also found differences in $\mathrm{CO}_{2}$ removal between species grown in traditional potting mix and hydroculture (Irga et al., 2013). Clearly, the substrate type is of importance in terms of $\mathrm{CO}_{2}$ removal, and this should be further investigated in subsequent studies. Additionally, this needs to be kept in context of the fact that overall capacity of individual plants to remove $\mathrm{CO}_{2}$ indoors is small (Pennisi and van lersel, 2012; Irga et al., 2013; Torpy et al., 2014; Torpy et al., 2017; Gubb et al., 2018). Furthermore, while we have expressed our $\mathrm{CO}_{2}$ removal data per unit leaf area (thus taking differences in plant size into the account), we cannot exclude possible impact of age differences between the plants. We made every effort to source the plants simultaneously, but their lifecycle and management prior to reaching us were beyond our control. Moreover, the authors acknowledge that photosynthetic activity can be reduced at high RH (Sailsbury and Ross, 1991), and therefore the results may have underestimated the $\mathrm{CO}_{2}$ removal in some treatments.

At 'no' and 'low' light levels typically experienced in indoor environments (Hawkins, 2011), most of the studied taxa would increase the concentration of $\mathrm{CO}_{2}$ in indoor environments as measured in our earlier leaf-level work (Gubb et al., 2018). However, Hedera, the taxon which potted in a Substrate 1 respired most, increased the $\mathrm{CO}_{2}$ concentration by $115 \mathrm{ppm} \mathrm{hr}^{-1}$ (i.e. $0.2 \mathrm{~g} \mathrm{~m}^{-3} \mathrm{hr}^{-1}$ ); comparatively, each person contributes $36 \mathrm{~g} \mathrm{hr}^{-1}$ of $\mathrm{CO}_{2}$ in an office environment (Persily and de Jonge, 2017). The contribution of plants to $\mathrm{CO}_{2}$ concentration increases can therefore 
be considered negligible in comparison to human contributions indoors at $\sim 0.6 \%$ of a humans contribution, in agreement with prior experiments (Gubb et al., 2018).

Our study clearly suggests that increasing the lighting levels indoors - made possible with targeted lighting installations - would allow taxa to significantly reduce $\mathrm{CO}_{2}$ concentration. This agrees with other similar studies, which show that light is the limiting factor for $\mathrm{CO}_{2}$ reduction indoors (Pennisi and van lersel, 2012; Gubb et al., 2018) and that houseplants can be expected to aid ventilation systems - by providing additional $\mathrm{CO}_{2}$ removal - but not replace them completely (Torpy et al., 2014).

The results of the current study allow us to estimate the number of houseplants required to reduce $\mathrm{CO}_{2}$ concentrations to a safe acceptable indoor level - literature suggests that concentrations of $600 \mathrm{ppm}$ and below cause fewer health issues then elevated $\mathrm{CO}_{2}$ concentrations (Seppanen et al., 1999; Erdmann and Apte, 2004; Allen et al., 2016) Therefore, for a small office of $15 \mathrm{~m}^{3}\left(11 \mathrm{~m}^{3}\right.$ is the minimum space required per person; HSE, 1992), we calculated the time required for a 'dry' Dracaena fragrans 'Golden Coast' potted in the Substrate 2 (as this plant/substrate combination led to most $\mathrm{CO}_{2}$ removal under our experimental conditions) to remove $400 \mathrm{ppm}$ of $\mathrm{CO}_{2}$ (i.e. reduce $\mathrm{CO}_{2}$ concentration from 1000 to $600 \mathrm{ppm}$ ), at a 'very high' light level assuming a sealed environment with no other sources of $\mathrm{CO}_{2}$ (Equation 1).

Time per $\mathrm{m}^{2}$ of $\mathrm{LA}(\mathrm{hr})=$ Concentration of $\mathrm{CO}_{2}$ to remove $(\mathrm{ppm}) /$ Rate of $\mathrm{CO}_{2}$ removal $\left(\mathrm{ppm} \mathrm{m} \mathrm{m}^{-2} \mathrm{hr}^{-1}\right) \times 1 / 100$

Taking into account volumetric loading differences (Girman, 1992) between the test chamber $\left(0.15 \mathrm{~m}^{3}\right)$ and the small office $\left(15 \mathrm{~m}^{3}\right)$, the rate of $\mathrm{CO}_{2}$ removal is reduced by a factor of 100 . Consequently, from the results in Figure 2 we estimate $2 \mathrm{~m}^{2}$ of Dracaena fragrans 'Golden Coast' (equating to 14 plants) in 'dry' conditions would require $12 \mathrm{hr}$ to remove $400 \mathrm{ppm}$ of $\mathrm{CO}_{2}$ in the office as per the above stipulated conditions.

Differences in removal between 'dry' and 'wet' conditions across taxa at all light levels and substrates was deemed negligible in agreement with (Gubb et al., 2018). This indicates that if plants are left to dry out - anecdotally a common occurrence - the impact on a room scale $\mathrm{CO}_{2}$ flux is small, although on a leaf level there are differences in $\mathrm{CO}_{2}$ assimilation. Additionally, at 'no' and 'low' light levels most taxa (i.e. the overall system) were respiring. Our study suggests that although at typical 'no' indoor light all studied taxa added $\mathrm{CO}_{2}$ to the indoor environment, the highest increase was approximately half the $\mathrm{CO}_{2}$ concentration removed at 'very high' light levels. This current work therefore confirms that placing a number of the studied houseplants in a typical home/office environment would not significantly damage health by increasing $\mathrm{CO}_{2}$ concentrations indoors under either 'wet' or 'dry' substrate conditions.

Even at 'very high' light levels, both Spathiphyllum wallisii 'Verdi' and Hedera helix would require an unrealistic number of plants in both substrates to reduce $\mathrm{CO}_{2}$ concentrations from $1000 \mathrm{ppm}$ to a near-ambient level. This is in contrast with plants' pronounced benefits in health and productivity terms (Park and Mattson, 2008; Park and Mattson, 2009; Shibata and Suzuki, 2002; Shibata and Suzuki, 2004). 
Our findings support the notion that the light level significantly impacts $\mathrm{CO}_{2}$ removal, as suggested in previous studies (Pennisi and van lersel, 2012; Torpy et al., 2014; Torpy et al., 2017; Gubb et al., 2018). Other previous work had also determined that unrealistic numbers of plants $(>200)$ are required to remove a significant amount of $\mathrm{CO}_{2}$ in indoor environments (Pennisi and van lersel, 2012; Torpy et al., 2014). These studies, however, did not take into account substrate moisture differences, or ambient $\mathrm{CO}_{2}$ concentrations (Pennisi and van lersel, 2012). Other studies did not specify which, or how many taxa provided any $\mathrm{CO}_{2}$ removal (Lim et al., 2009; Pegas et al., 2012), or only considered one light level (Oh et al., 2011).

Torpy et al., 2017 estimated that a $2 \mathrm{~m}^{2}$ active green wall of Chlorophytum comosum (where substrate is actively ventilated by pushing air through it) in peat-free substrate would be capable of removing $11 \mathrm{~g}$ of $\mathrm{CO}_{2}$ per hour in a $16 \mathrm{~m}^{3}$ room. Our previous work estimated that $2 \mathrm{~m}^{2}$ (of leaf area) of Spathiphyllum wallisii 'Verdi' in unventilated peat-free substrate removed $0.75 \mathrm{~g}_{\text {of }} \mathrm{CO}_{2}$ per hour at a comparable light level (Gubb et al., 2018). This current work estimated that $2 \mathrm{~m}^{2}$ (of leaf area) of Dracaena fragrans 'Golden Coast' at a light level comparable to both of the previous removes $3 \mathrm{~g}$ per $\mathrm{m}^{3}$ of $\mathrm{CO}_{2}$ per hour in a $15 \mathrm{~m}^{3} \mathrm{room}$, clearly highlighting the benefits of 'active' walls (i.e. substrate ventilation) opposed to traditional 'passive' houseplants.

We support the notion that any future work should focus on green walls (Pettit et al., 2017; Torpy et al., 2017) (especially 'active' walls) which yield more effective removal due to an increased LA of taxa and increased substrate airflow. Additionally, taxa which have performed well in removing other indoor pollutants at high indoor light levels i.e. Osmunda japonica (Kim et al., 2010) should be further examined. Furthermore, more substrate types should also be investigated. This study has shown that the ability of plants to remove $\mathrm{CO}_{2}$ at typical indoor light levels may be maximised with certain substrate types and moisture conditions, therefore lower - more realistic numbers of plants may be required to reduce harmful concentrations of $\mathrm{CO}_{2}$. Additionally, as 'active' walls - which are clearly superior removers - place extra emphasis on the substrate, removal differences between substrate types will likely be further highlighted.

\section{Conclusion}

The study confirmed that growing the same taxa in differing substrates significantly influenced removal ability in most of the studied species - highlighting the key role substrate types play. The results from the current work indicates that $2 \mathrm{~m}^{2}$ of Dracaena fragrans 'Golden Coast' would require $12 \mathrm{hr}$ at a 'very high' light level ( 22000 lux) in 'dry' conditions to reduce $1000 \mathrm{ppm}$ of $\mathrm{CO}_{2}$ - the ASHRAE recommended maximum $8 \mathrm{hr}$ exposure guideline to a $600 \mathrm{ppm}$ concentration in a $15 \mathrm{~m}^{3}$ closed environment (i.e. small office) with no other sources of $\mathrm{CO}_{2}$. Other studied taxa (Spathiphyllum wallisii 'Verdi' and Hedera helix) were found to require an unrealistic number of plants at the same 'very high' light level.

At typical 'no' and 'low' indoor light levels most studied houseplants increased $\mathrm{CO}_{2}$ concentrations albeit, for the highest respiring taxa at approximately half the concentration removed at 'very high' light. Therefore, none of the studied houseplants would significantly elevate $\mathrm{CO}_{2}$ concentrations indoors and thus, cause detrimental health effects. Differences between 'dry' and 'wet' substrates in their capacity for $\mathrm{CO}_{2}$ removal at either 'no', 'low' or 'very 
1 high' light can be considered negligible. Our findings support the notion that raising the light level indoors is

2 paramount for studied taxa to remove $\mathrm{CO}_{2}$ 


\section{References}

Agus F, Hairiah K \& A, M. (2011). Measuring Carbon Stock In Peat Soils: Practical guidelines. Bogor, Indonesia: World Agroforestry Centre (ICRAF).

Alexander, P. D., Williams, R. H. \& Nevison, I. M. (2013). Improving gardeners' understanding of water management in peat and peat-free multi-purpose growing media: An assessment with fuchsia. Acta Horticulturae, 1013, 257-264.

Allen, J. G., MacNaughton, P., Satish, U., Santanam, S., Vallarino, J. \& Spengler, J. D. (2016). Associations of Cognitive Function Scores with Carbon Dioxide, Ventilation, and Volatile Organic Compound Exposures in Office Workers: A Controlled Exposure Study of Green and Conventional Office Environments. Environmental Health Perspectives, 124, 805-812.

Barrett, G. E., Alexander, P. D., Robinson, J. S. \& Bragg, N. C. (2016). Achieving environmentally sustainable growing media for soilless plant cultivation systems - A review. Scientia Horticulturae, 212, 220-234.

Boyce, P. \& Raynham, P. (2009). The SLL Lighting Handbook, London, The Society of Light and Lighting.

Cook, F. J., Orchard, V. A. \& Corderoy, D. M. (1985). Effects of lime and water content on soil respiration. New Zealand Journal of Agricultural Research, 28, 517-523.

Cruz, M. D., Christensen, J. H., Thomsen, J. D. \& Muller, R. (2014). Can ornamental potted plants remove volatile organic compounds from indoor air? - a review. Environmental Science and Pollution Research, 21, 13909-13928.

De Kempeneer, L., Sercu, B., Vanbrabant, W., Van Langenhove, H. \& Verstraete, W. (2004). Bioaugmentation of the phyllosphere for the removal of toluene from indoor air. Applied Microbiology and Biotechnology, 64, 284-288.

Defra (2018). A Green Future: Our 25 Year Plan To Improve The Environment. London: Defra.

Erdmann, C. A. \& Apte, M. G. (2004). Mucous membrane and lower respiratory building related symptoms in relation to indoor carbon dioxide concentrations in the 100-building BASE dataset. Indoor Air, 14, 127-134.

Gaihre, S., Semple, S., Miller, J., Fielding, S. \& Turner, S. (2014). Classroom Carbon Dioxide Concentration, School Attendance, and Educational Attainment. Journal of School Health, 84, 569-574.

Girman, J. R. (1992). Comment on the use of plants as a means to control indoor air pollution. In: EPA (United States Environ. Prot. Agency) - NSCEP (National Serv Cent Environ Publ). URL:

https://nepis.epa.gov/Exe/ZyNET.exe/000002IB.TXT?ZyActionD=ZyDocument\&Client=EPA\&Index=1991+Thru+1994\&D ocs $=$ \&Query=\&Time $=$ \&EndTime $=\&$ SearchMethod $=1 \&$ TocRestrict $=$ n \&Toc $=\&$ TocEntry $=\& Q$ Field $=\& Q$ Field Year $=\& Q F i e l d M$ onth=\&QFieldDay=\&IntQFieldOp=0\&ExtQFieldOp=0\&XmlQuery=\&File=D\%3A\%5Czyfiles\%5CIndex\%20Data\%5C91thru9 4\%5CTxt\%5C00000002\%5C000002IB.txt\&User=ANONYMOUS\&Password=anonymous\&SortMethod=h\%7C\&MaximumDocuments=1\&FuzzyDegree=0\&ImageQuality=r75g8/r75g8/x150y150g16/i425\&Display=hpfr\&DefSeekPage =x\&SearchBack=ZyActionL\&Back=ZyActionS\&BackDesc=Results\%20page\&MaximumPages=1\&ZyEntry=1\&SeekPage=x\& ZyPURL [22 APR 2018].

Gubb, C., Blanusa, T., Griffiths, A. \& Pfrang, C. (2018). Can houseplants improve indoor air quality by removing CO2 and increasing relative humidity? Air Quality, Atmosphere and Health, 11, 1191-1201.

Hawkins, G. (2011). Rules of Thumb: Guidelines for building services. 5 ed. Bracknell, UK: BSRIA.

HSE (1992). L24: Workplace Health, Safety and Welfare Regulations 1992: Approved Code of Practice. UK: Health and Safety Executive (HSE)

Huang, L., Zhu, Y., Ouyang, Q. \& Cao, B. (2012). A study on the effects of thermal, luminous, and acoustic environments on indoor environmental comfort in offices. Building and Environment, 49, 304-309.

Irga, P. J., Torpy, F. R. \& Burchett, M. D. (2013). Can hydroculture be used to enhance the performance of indoor plants for the removal of air pollutants? Atmospheric Environment, 77, 267-271.

Irga, P. J., Pettit, T. J. \& Torpy, F. R. (2018). The phytoremediation of indoor air pollution: a review on the technology development from the potted plant through to functional green wall biofilters. Reviews in Environmental Science and Bio-Technology, 17, 395-415.

Kim, K. J., Il Jeong, M., Lee, D. W., Song, J. S., Kim, H. D., Yoo, E. H., Jeong, S. J., Han, S. W., Kays, S. J., Lim, Y.-W. \& Kim, H.-H. (2010). Variation in Formaldehyde Removal Efficiency among Indoor Plant Species. Hortscience, 45, 1489-1495.

Kim, K. J., Khalekuzzaman, M., Suh, J. N., Kim, H. J., Shagol, C., Kim, H.-H. \& Kim, H. J. (2018). Phytoremediation of volatile organic compounds by indoor plants: a review. Horticulture Environment and Biotechnology, 59, 143-157.

Kim, K. J., Kil, M. J., Song, J. S., Yoo, E. H., Son, K.-C. \& Kays, S. J. (2008). Efficiency of volatile formaldehyde removal by indoor plants: Contribution of aerial plant parts versus the root zone. Journal of the American Society for Horticultural Science, 133, 521-526.

Lai, A. C. K., Mui, K. W., Wong, L. T. \& Law, L. Y. (2009). An evaluation model for indoor environmental quality (IEQ) acceptance in residential buildings. Energy and Buildings, 41, 930-936.

Lim, Y.-W., Kim, H.-H., Yang, J.-Y., Kim, K.-J., Lee, J.-Y. \& Shin, D.-C. (2009). Improvement of Indoor Air Quality by Houseplants in New-built Apartment Buildings. Journal of the Japanese Society for Horticultural Science, 78, 456-462.

Manzoni, S. (2012). Responses of soil microbial communities to water stress: results from a meta-analysis. Ecology, 93, 930-939. 
Oh, G. S., Jung, G. J., Seo, M. H. \& Im, Y. B. (2011). Experimental study on variations of $\mathrm{CO}_{2}$ concentration in the presence of indoor plants and respiration of experimental animals. Horticulture Environment and Biotechnology, 52, 321-329.

Orwell, R. L., Wood, R. L., Tarran, J., Torpy, F. \& Burchett, M. D. (2004). Removal of benzene by the indoor plant/substrate microcosm and implications for air quality. Water Air and Soil Pollution, 157, 193-207.

Park, S.-H. \& Mattson, R. H. (2008). Effects of flowering and foliage plants in hospital rooms on patients recovering from abdominal surgery. Horttechnology, 18, 563-568.

Park, S.-H. \& Mattson, R. H. (2009). Therapeutic Influences of Plants in Hospital Rooms on Surgical Recovery. Hortscience, 44, 102-105.

Pegas, P. N., Alves, C. A., Nunes, T., Bate-Epey, E. F., Evtyugina, M. \& Pio, C. A. (2012). Could Houseplants Improve Indoor air Quality in Schools? Journal of Toxicology and Environmental Health-Part a-Current Issues, 75, 1371-1380.

Pennisi, S. V. \& van lersel, M. W. (2012). Quantification of Carbon Assimilation of Plants in Simulated and In Situ Interiorscapes. Hortscience, 47, 468-476.

Perez-Lombard, L., Ortiz, J. \& Pout, C. (2008). A review on buildings energy consumption information. Energy and Buildings, 40, 394-398.

Persily, A. \& de Jonge, L. (2017). Carbon dioxide generation rates for building occupants. Indoor air, 27, 868-879.

Pettit, T., Irga, P. J., Abdo, P. \& Torpy, F. R. (2017). Do the plants in functional green walls contribute to their ability to filter :particulate matter? Building and Environment, 125, 299-307.

Sailsbury, F. B. \& Ross, C. W. (1991). Plant Physiology, Belmont California U.S.A, Wadsworth Publishing Company.

Satish, U., Mendell, M. J., Shekhar, K., Hotchi, T., Sullivan, D., Streufert, S. \& Fisk, W. J. (2012). Is CO2 an Indoor Pollutant? Direct Effects of Low-to-Moderate CO2 Concentrations on Human Decision-Making Performance. Environmental Health Perspectives, 120, 1671-1677.

Schmilewski, G. (2008). The role of peat in assuring the quality of growing media. Mires and Peat, 3, 1-8.

Seppanen, O. A., Fisk, W. J. \& Mendell, M. J. (1999). Association of ventilation rates and CO2 concentrations with health and other responses in commercial and institutional buildings. Indoor Air-International Journal of Indoor Air Quality and Climate, 9, 226-252.

Shaughnessy, R. J., Haverinen-Shaughnessy, U., Nevalainen, A. \& Moschandreas, D. (2006). The effects of classroom air temperature and outdoor air supply rate on the performance of school work by children. Indoor Air, 16, 465-468.

Shendell, D. G., Prill, R., Fisk, W. J., Apte, M. G., Blake, D. \& Faulkner, D. (2004). Associations between classroom CO2 concentrations and student attendance in Washington and Idaho. Indoor Air, 14, 333-341.

Shibata, S. \& Suzuki, N. (2002). Effects of the foliage plant on task performance and mood. Journal of Environmental Psychology, 22, 265-272.

Shibata, S. \& Suzuki, N. (2004). Effects of an indoor plant on creative task performance and mood. Scandinavian Journal of Psychology, 45, 373-381.

Torpy, F. R., Irga, P. J. \& Burchett, M. D. (2014). Profiling indoor plants for the amelioration of high CO2 concentrations. Urban Forestry \& Urban Greening, 13, 227-233.

Torpy, F. R., Zavattaro, M. \& Irga, P. J. (2017). Green wall technology for the phytoremediation of indoor air: a system for the reduction of high CO2 concentrations. Air Quality Atmosphere and Health, 10, 575-585.

Tsai, D.-H., Lin, J.-S. \& Chan, C.-C. (2012). Office Workers' Sick Building Syndrome and Indoor Carbon Dioxide Concentrations. Journal of Occupational and Environmental Hygiene, 9, 345-351.

Vaz Monteiro, M., Blanusa, T., Verhoef, A., Hadley, P. \& Cameron, R. W. F. (2016). Relative importance of transpiration rate and leaf morphological traits for the regulation of leaf temperature. Australian Journal of Botany, 64, 32-44.

Vehvilainen, T. y., Lindholm, H., Rintamaki, H., Paakkonen, R., Hirvonen, A., Niemi, O. \& Vinha, J. (2016). High indoor CO2 concentrations in an office environment increases the transcutaneous $\mathrm{CO} 2$ level and sleepiness during cognitive work. Journal of Occupational and Environmental Hygiene, 13, 19-29.

Weyens, N., Thijs, S., Popek, R., Witters, N., Przybysz, A., Espenshade, J., Gawronska, H., Vangronsveld, J. \& Gawronski, S. W. (2015). The Role of Plant-Microbe Interactions and Their Exploitation for Phytoremediation of Air Pollutants. International Journal of Molecular Sciences, 16, 25576-256042

Wood, R. A., Orwell, R. L., Tarran, J., Torpy, F. \& Burchett, M. (2002). Potted-plant/growth media interactions and capacities for removal of volatiles from indoor air. Journal of Horticultural Science \& Biotechnology, 77, 120-129.

Zhang, H., Pennisi, S. V., Kays, S. J. \& Habteselassie, M. Y. (2013). Isolation and Identification of Toluene-Metabolizing Bacteria from Rhizospheres of Two Indoor Plants. Water Air and Soil Pollution, 224.

Zhang, X., Wargocki, P. \& Lian, Z. (2017). Physiological responses during exposure to carbon dioxide and bioeffluents at levels typically occurring indoors. Indoor Air, 27, 65-77. 